\title{
Methodological interests and the teaching of research methods in Latin America
}

\author{
Juan Ignacio Piovani \\ Professor at National University of La Plata and researcher at the National Scientific \\ and Technical Research Council (CONICET) (Argentina).
}

\begin{abstract}
This article analyzes a series of historical processes related to the development of shared methodological interests within the community of Latin American social scientists. First, it illustrates how a specific methodological field emerged as part of the institutionalization and professionalization of the social sciences, especially in the US, and how the methodological concerns and debates changed over time. On the other hand, it describes the repercussions of these processes in Latin America, particularly for the emergence of a "scientific" sociology, and how the accumulation of experiences related to the methodological field led to the establishment of specialized institutions in the region, such as the Latin American Network of Social Science Methodology (RedMet). With regard to the methodological interests of Latin American academics, the article focuses on those that have been put forward in the regional congresses of social science methodology (ELMECS) organized biannually by RedMet and, in particular, on the problem of the teaching and learning of research methods, that has been a core concern in all the different countries and institutions. Within this broad interest related to the teaching of methodology, special attention is paid to the results of empirical research conducted on how methods are actually taught in various $\mathrm{PhD}$ programs of different Latin American universities from Argentina, Brazil and Mexico.
\end{abstract}

Keywords: Latin America. Networks. Methodology. Teaching. 
Tf method is taken in its etymological definition - i.e. "the way by Lwhich" - then we must admit that, at least in some sense, the issue of method has always been around in the processes of knowledge construction. However, such processes have also been the subject of reflection since ancient times: already in classic Greek philosophy, sophisticated speculations on knowledge can be found which established the basis of the theory of knowledge.

In the scientific field, according to Marradi (2002), the first discussion on method dates back to mid sixteenth century, although it would only gain centrality in the next century, following the publication of Discours de la Méthode by Descartes (1637).

As to social sciences, methodological issues constituted a matter of concern since its beginning. Among the classics, Durkheim stands out. His work on The Rules of Sociological Method (1895) laid the foundations of an empirical positivist social science. The Weberian formulation of an interpretative social science is equally recognized, being a mandatory reference of qualitative methods.

However, methodology as an institutionalized knowledge area is relatively recent: in sociology, for example, it begins to acquire its own status and identity around the 1920s, following the creation of university departments and disciplinary research centers. In the context of the specialized - and professionalized - academic work conducted in these institutional spaces, the need to produce a body of specific knowledge regarding research practices (approaches, concepts, instruments) and the ways of transmitting them emerged gradually (Piovani, 2011).

The Department of Sociology at the University of Chicago, first of its kind worldwide, comprises a paradigmatic case of this process. As of the second decade of the twentieth century, research conducted in the Department began to acquire a high degree of sophistication and, from then on, the "methodological awareness", as Bulmer (1984) called it, would gradually develop. 
Moreover, around the 1920 decade, the rationales for training of researchers were already well established in Chicago. Yet, for lacking adequate teaching materials (apart from the handbook usually known as Green Bible $)$, the intellectual leaders of the Department - Park and Burgess - who were in charge of teaching the doctoral seminar on research, hired the British sociologist V. Palmer for systematizing the lessons taught in this area into a specialized manuscript. Such manuscript came to be the well-known Field Methods in Sociology (1928), one of the first handbooks of methodology in the Social Sciences, besides those of Borgadus: Making social science studies (1918) and The social new research (1926); Chapin: Fieldwork and social research (1920); Odum and Jocher: An introduction to social research (1929); Lundberg: Social research (1929); Elmer: Social Research (1939) and Young: Scientific social survey and research (1939).

As of the 1940s and 1950s, and especially in the context of the North American sociology, methodology gained a new impetus from the hands of intellectual leaders as Lazarsfeld, all of whom helped to consolidate its place as one of the pillars of university education and to recognize it as a legitimate field of theoretical and empirical inquiry. However, in this context, which Giddens (1979) labels as the "orthodox consensus" of the social sciences, and following an initial stage characterized as "pluralistic", the corpus of objectified methodological knowledge has been increasingly reduced to that which we know today as quantitative methods.

Such methodological perspective, which was then internationally dominant, had a significant influence during the 1950s in the emergence of a "scientific" sociology in Latin America. In this respect, suffice it to remember the emphasis given by Germani (1962), a key personage (at least in Argentina) in the institutionalization and professionalization

1 Introduction to the Science of Sociology, by Park and Burgess (1921), commonly known as "Green Bible" because it has quickly gained the status of a kind of "bible" for sociologists' training during the 1920s. 
of sociology, to the teaching of methodology and research techniques. Following Damiano (2009), we could say that this project of a scientific sociology was characterized, above all, by the effort to align Latin American social sciences with the international developments that are presented by Germani as follows: proliferation of specialized schools, departments and faculties; universalization of concepts, problems and theories; and refinement of research techniques.

Back again, in a few words, to methodology at the global level, between the late 1960s and the early 1970s - period characterized by the crisis of the orthodox consensus - increasing criticism of the quantitative approach emerged, making room for a progressive legitimization of qualitative approaches. Furthermore, and to some extent in line with the aforementioned criticism, the broad epistemological and methodological debates got a new perspective.

However, despite this remarkable development experienced during the second half of the twentieth century, debates persist on whether Methodology is either an academic field, or a discipline or sub-discipline of social sciences, or else whether it is simply an auxiliary set of knowledge applicable to various scientific contexts irrespective of their specificities.

Without going deep into this debate, the current existence of academic networks, research centers, publications, graduate programs and national and international conferences specialized in Methodology of the Social Sciences clearly fulfils MacKenzie's (1981) main postulates defining the status of a discipline as such.

As for Latin America, without disregarding the various institutional experiences related to the development of methodological studies, it is worth highlighting that the Asociación Latinoamericana de Sociología (ALAS) has long since created the Working Group on Epistemology and Methodology, within which hundreds of different works have been submitted, and which has promoted exchange between scholars from different countries and institutions in the region. It was at a Congress of ALAS, held in 2005 in Brazil, that a collaborative work was started, 
which later gave rise to the Latin American Network of Social Sciences Methodology (RedMet). The network initiated by a group of teachers and researchers from Argentina, Brazil, Chile and Uruguay has soon been joined by colleagues from Peru, Mexico, Colombia, Venezuela and Costa Rica. Since its establishment, RedMet's two most important activities have been organizing the Latin American Social Sciences Methodology Meetings (ELMECS) ${ }^{2}$ and editing the Latin American Journal of Social Sciences Methodology (RELMECS) ${ }^{3}$.

Notwithstanding the diversity of perspectives included in RedMet, the network's trademark is a critical orientation that, as regards to methodological problems, entails keeping away from a perspective prone to reduce the complex framework of decisions involved in the process of knowledge construction to a mere formal and technical matter. Furthermore, it tends to join a tradition, held by Marradi (2002), that considers Methodology as in permanent dialectical tension between the poles of a continuum represented, on one side, by the study of the epistemological postulates that enable social knowledge and, on the other side, by the research techniques (in the sense of Gallino, 1978). As Bruschi (1991) points out, if methodology renounces its epistemological aspect, it will be reduced to a technology no longer intellectually controllable; but, if its technical aspect is abandoned, it becomes a pure philosophical reflection on social sciences, unable to influence the activities of empirical research.

This requires connecting the discussion about epistemological aspects to the specific research practices and to the techniques and instruments that enable them, while thematizing their historical origins,

2 To date four ELMECS have been held: La Plata (Argentina), 2008; Hermosillo (Mexico), 2010; Manizales (Colombia), 2012; and Heredia (Costa Rica), 2014.

3 This journal, which adds to the list of recognized publications in the area such as Cinta de Moebio, Perspectivas Metodológicas and RELMIS, among others, constitutes a new milestone in the consolidation of methodological studies in Latin America. It aims to disseminate critical contributions related to Epistemology and Methodology, methods and techniques of social research (including conceptual and operational dimensions as well as its applications), the history of Methodology, social research methods and techniques and their teaching at the university. 
foundations and relations with different theoretical and philosophical perspectives. On the other hand, it involves recognizing the historical nature of specialized knowledge construction, and investigating the mechanisms through which shared methodological senses are produced and reproduced in the processes of secondary socialization of young researchers. Doing it from Latin America also requires discussing how adequate are the conceptual and operational instruments of canonical methodologies for dealing with the complex social reality that emerges in our continent.

As noted earlier, RedMet comprises a plurality of interests and perspectives on methodology currently arising in Latin America. This becomes evident when we analyze the series of thematic sessions that have been organized in the context of ELMECS. In addition to addressing the more general epistemological and methodological discussions, these sessions have had a focus on the advances in quantitative and qualitative methods and techniques; the triangulation and other forms of methodological integration or complementation; debates on the appropriateness of current approaches to address social problems that emerge in Latin America; inter and trans-disciplinary methodologies, as well as on a diverse range of methodological and technical discussions came out as a result of empirical researches on various issues, from social structure and stratification to public policies, to genders and sexualities, security and justice, migrations and displacement, education and work, among others.

Yet, maybe the matters that gather most attention in the context of RedMet's methodological discussions are those relating to the teaching and learning of methodology and research methods. In this regard, it is worth noting that 110 out of more than 850 papers presented throughout the history of ELMECS addressed this issue. Presentations on this theme accounted for $9 \%$ to $15 \%$ of all written papers submitted at each of the four meetings held to date, and the average number of papers presented in this specific thematic session has always been much 
higher than that of other sessions (between 33\% and 143\% higher, depending on the edition) $)^{4}$.

In the scope of these Latin American academic exchanges, the teaching and learning of methodology has been set out from various perspectives. To the same extent, different aspects of this issue have been addressed, among which the problem of how to learn to conduct research (by researching) and how to convey the "profession" of researcher (Barone, 2008; Mingo; Luque; Sioni, 2010; Pacheco Espejel, 2010; Cifuentes, 2014; Seid; Malegarie; Fernandez, 2014); how to teach methodology in particular disciplines of social sciences (Calvo, 2008; Cuenca; Martello; Di Marco, 2008; Orler, 2010; Parra; Areta, 2010; Salanueva; Gonzalez, 2010; Sotomayor Peterson, 2010; Maidana; Libonatti, 2010; Besora; Bustamante; Lesta, 2012); how to train students for research design and for setting out problems and /or hypotheses (Gasca Salas, 2008; Izura; della Torre, 2008; Lince Campillo; Camacho Castillo, 2010; Blazsek et al, 2012;. Moraga Catalán, 2014); how to facilitate the development of undergraduate and graduate thesis (Rusque; Gutierrez, 2010; Torres; Izura, 2012; Badano, 2012; Soto Acosta; Salas Ocampo, 2014) .

Another trend in this field rather points to the empirical analysis of strategies and projects involving the teaching of methodology as performed in various national and institutional contexts. In this sense, it is not intended to establish a proposal on what or how to teach, but rather to know what is taught and how it is done.

Within this line of work, I have participated in research projects focused specifically on the teaching of methodology in comparative

\footnotetext{
4 On the other hand, plenary panels and public lectures on this theme have been frequent at ELMECS, as well as other events organized under the auspices of RedMet, particularly in Colombia and Mexico. In this regard, it is worth mentioning the First International Symposium: "The current state of teaching-learning of social sciences research methodology in Latin America" organized by the National Autonomous University of Mexico (UNAM) in 2013.

Papers of 2008 can be found in: Tortti, C. and Piovani, J. I. (2008); of 2010 in: Gutiérrez Rohán, D. et al. (2010); of 2012 in: Castellanos, J. M.; Carreño, M. T. and Piovani, J. I. (2012) and of 2014 in the Actas Electrónicas del IV ELMECS: http://elmecs.fahce.unlp.edu.ar/iv-elmecs
} 
perspective ${ }^{6}$, having as reference $\mathrm{PhD}$ programs of various leading universities $^{7}$ of the region (see Piovani et al., 2012; Piovani, Rausky; Santos, 2012; Piovani, 2013, 2014a, 2014b). The range of cognitive problems involved in these projects can be summarized in a set of questions as, among others: How institutionalized are the methodology courses? What conceptions are predominant in these courses? How is the classic qualitative/quantitative debate presented? How the methodological ideas developed in the main centers of knowledge production are received and resignified? How the shared senses about what it is to do social research are produced and reproduced in the context of secondary socialization? In order to address some of these questions, we have analyzed the curricula of the $\mathrm{PhD}$ Programs and the syllabuses of methodology courses (foundations, objectives, contents, bibliography). Complementarily, we have carried out in-depth interviews with teachers of methodology and with doctoral students selected in accordance to the principles of purposive sampling.

The study of the curricula and the syllabuses was structured, in each case, on the basis of some key questions:

a. Doctoral Program/Curriculum: how is it structured? What and how many methodological subjects does it include? What type of methodological courses and seminars? How are they hinged together and with other subjects? Are they mandatory or optional? How do they relate to research design, research practices and the conduct of the $\mathrm{PhD}$ dissertation?

\footnotetext{
6 These projects have involved the analyses of the teaching of research methods in Argentina, Brazil and Mexico. The Brazilian case has been addressed jointly with N. Aliano, V. Ardenghi, S. Balerdi, N. Herrera, R. Iuliano, M. Massini, N. Stefoni and N. Welschinger. The Argentinean case has been studied with E. Rausky and J. Santos. The Mexican case has been focused by E. Arce and O. Boix.

Argentina: Universidad de Buenos Aires, Universidad Nacional de La Plata, Universidad Nacional de General Sarmiento/Brazil: Universidade Federal do Rio de Janeiro, Universidade do Estado do Rio de Janerio, Pontifícia Universidade Católica do Rio de Janeiro, Universidade de São Paolo, Universidade Estadual de Campinas/México: Facultad Latinoamericana de Ciencias Sociales, Universidad Nacional Autónoma de México.
} 
b. Methodological course's syllabus: how is the course organized? What are its objectives? What contents does it cover? How are the contents structured? Does it include a practical instance? Is there a link between the contents of the course and the topics of the students' dissertations? What bibliography is used? Who is (are) the author(s) of each text cited in the bibliography? What is the date of publication? Where was it published (original and translation, if applicable)? In what language? What methodological issues are treated in each text? What is its epistemological, methodological and theoretical orientation? How is considered the adequacy of the bibliographic material for the topics addressed in the course? How is the academic profile of the lecturer(s) in charge of the course?

From the analyses performed, we found that the ways of solving problems and tensions related to the training of social scientists in methodology, in the scope of university programs, have led to different traditions that can be regarded as part of a continuum. On the one hand, there is the strategy based on the idea that Methodology constitutes a specific field, defined by a set of objectified knowledge that can be transmitted per se, regardless of research practices in which they are inserted. On the other hand, Methodology's identity is blurred and its knowledge is subsumed into practices: "one learns to investigate by investigating" and, therefore, Methodology does not need nor should be taught as a formal course. Methodological training of future researchers should rather be carried out by their immersion in research practices (and under the supervision of an experienced tutor).

Here, it is worth emphasizing the presumed risks entailed in both traditions, at least in their most radical versions: first, the risk of Methodology to become an unfruitful, purely speculative knowledge, unable to be adequately employed in research practices; on the other side, the tendency to reproduce research practices that are conducted without critically reflecting about the methodological choices that enable 
the construction of knowledge and, thus, reinforcing the practice of a methodologically recursive "normal" science (as put by Kuhn, 1962).

However, we should highlight that the studied cases from Argentina, Brazil and Mexico are distant from these extreme positions. On the contrary, there is a clear effort to transcend the antagonism between, on the one hand, the speculative and theoretical education (that dispense with the practice) and, on the other hand, the training "through" practice (that dispense with the formal education in the objectified research techniques and/or the methodological reflection regarding such practices), although in some contexts there have been a tendency towards the first pole and in others towards the second. A common strategy for filling this gap between theoretical teaching of methodology and research practice has been the creation of increasing venues for discussion and follow-up of doctoral thesis, particularly in the form of workshops.

Another common aspect of methodology training offered by the graduate programs studied is that such training tends to be concentrated in the initial stages of the degree, as part of a vertical strategy connecting a theoretical stage to a more research-oriented stage. Thus, the structured schooling (sometimes embodied in a Masters) precedes the development of a doctoral research project and the subsequent writing of the thesis.

Furthermore, we observe in the curricula of Latin American graduate programs a certain repositioning of quantitative methods, apparently overcoming the stigmatization that prevailed during the period referred by Pawson (1994), to account for the historical phases of the quantitative-qualitative debate, as "methodolatry". However, this cannot be directly regarded as a turn of page in relation to methodological antagonism, because curricula are often defined in terms of such opposition, and also because syllabuses in specific subjects hardly ever have contents related to methodological articulation/mixing/ complementarity. This situation regarding the classification of courses 
as quantitative or qualitative reproduces what Gugliano and Robertt (2010) suggest referring to undergraduate education in Brazil, and that also applies largely to other Latin American countries. Yet, in line with a suggestion by these authors, such didactic organization of Methodology seems no longer to respond to an inflexible epistemological stance that understands each method as the fulfillment of the assumptions and basis of incommensurable paradigms (Bryman, 1988). Rather, the situation could be best characterized in terms of what Pawson (1994) calls "pragmatic pluralism".

Finally, it is also worth noting that the greater or lesser presence of formal methodological courses in the training of social researchers tends to be correlated with the situation of Methodology as a knowledge field in the institutional contexts in which $\mathrm{PhD}$ programs are developed. In general, the teaching of methodology is more problematized in those contexts where there is a greater tradition in methodological research and production of specialized texts on the subject. In regard to the literature, some countries (such as Mexico and Argentina) usually count on domestically produced specific works. In other countries, in contrast, the use of local texts is rather limited to the illustration of a particular method or technique through empirical research. In any case, the international literature is still very important to address epistemological and theoretical issues (specially the European one) as well as the methodological and technical issues (importantly represented by American literature and other texts originally published in English).

\section{References}

BOGARDUS, E.S. Making Social Science Studies. Los Angeles: Jesse Ray Miller, (1918)1925.

BOGARDUS, E.S. The New Social Research. Los Angeles: Jesse Ray Miller, 1926.

BRUSCHI, A. Logica e metodologia. Sociologia e ricerca sociale, v. 35, 1991, p. 30-55.

BRYMAN, A. Quantity and quality in social research. Londres: Routledge, 1988.

BULMER, M. The Chicago School of Sociology: Institutionalization, Diversity, and the Rise of Sociological Research. Chicago: University Press, 1984. 
CASTEllanOS, J. M.; CARREÑO, M. T.; PIOVANI, J. I. Construcción de opciones metodológicas para las ciencias sociales contemporáneas. Memorias del III ELMeCS. Manizales: Universidad de Caldas, 2012.

COHEN, N.; PIOVANI, J. I. La metodología de la investigación en debate. La Plata: Edulp Eudeba, 2008.

CHAPIN, S. F. Field Work and Social Research. New York: Appleton-Century, 1920.

DAMIANO, F. Enseñando a investigar: Gino Germani y la sociología científica. Revista Trabajo y Sociedad 13, XI, 2009.

DESCARTES, R. Discours de la méthode, 1637.

DURKHEIM, E. Les règles de la MéthodeSociologique. Paris: Félix Alcan, 1895.

ELMER, M. C. Social Research. Nueva York: Prentice Hall, 1939.

GALLINO Dizionario di Sociologia. Turín: UTET, 1978.

GERMANI, G. La sociología cientifica. México, UNAM, 1962.

GIDDENS, A. Central problems in social theory. Action, structure and contradiction in sociological analysis. Londres: Macmillan, 1979.

GUGLIANO, A.; ROBERTT, P. La Enseñanza de las Metodologías en las Ciencias Sociales en Brasil. CintaMoebio, v. 38, 2010, p. 61-71.

GUTIÉRREZ ROHÁN, D. et al. Actas del II Encuentro Latinoamericano de Metodología de las Ciencias Sociales. Hermosillo: UNISON, 2010.

KUHN, T. The Structure of Scientific Revolutions. Chicago: University Press, 1962.

LUNDBERG, G. A. Social research. Nueva York: Longman, Green \& Co., 1929/1941.

MacKENZIE, D. Statistics in Britain, 1865-1930. The Social Construction of Scientific Knowledge. Edinburgh: University Press, 1981.

MARRADI, A. El método como arte. Papers. Revista de Sociología, n. 67, 2002, p. 107-127.

ODUM, H. W.; JOCHER, K. An Introduction to Social Research. New York: Holt, 1929.

PALMER, V. M. Field studies in sociology: a student's manual. Chicago: University Press, 1928.

PARK, R.; BURGESS, E. Introduction to the Science of Sociology. Chicago: University of Chicago Press, 1921.

PAWSON, R. "Quality and quantity, Agency and structure, mechanism and context, dons and cons”. In: World Congress of Sociology. Bielefeld: ISA, 1994.

PIOVANI, J. I. La Metodología de las Ciencias Sociales como campo de interés intelectual en América Latina. Revista Latinoamericana de Metodología de las Ciencias Sociales, v. 1, n. 1, 2011, p. 1-7.

PIOVANI, J. I. Núcleos problemáticos en los procesos de formación metodológica de científicos sociales en América Latina. XXIX Congreso Latinoamericano de Sociología. Universidad de Chile. Santiago de Chile, 2013.

PIOVANI, J. I. Tendencias actuales en la enseñanza de la metodología en doctorados en ciencias sociales de Argentina y Brasil. In: GALLEGOS ELÍAS, C.; RINCÓN PÉREZ, F. (Eds.). ¿Cómo investigamos? ¿Cómo enseñamos a investigar? Tomo III. Tuxtla Gutiérrez, México: Unicach-Unam, $2014 a$. 
SOCIOLOGIES
in DIALOGUE

PIOVANI, J. I. La formazione metodológica dei ricercatori sociali in America Latina. Sociologia e ricerca sociale, v. 104, 2014b, p. 147-156.

PIOVANI, J.I. et al. La enseñanza de la metodología en posgrados universitarios de Ciencias Sociales de Brasil. III Encuentro Latinoamericano de Metodología de las Ciencias Sociales. RedMet UManizales - UCaldas, Manizales, Colombia, 2012.

PIOVANI, J. I.; RAUSKY, E.; SANTOS, J. La enseñanza de la metodología en posgrados universitarios de Ciencias Sociales de Argentina. VII Jornadas de Sociología. UNLP, La Plata, Argentina, 2012.

TORTTI, C.; PIOVANI, J. I. Actas del I Encuentro Latinoamericano de Metodología de las Ciencias Sociales. La Plata: FaHCE-UNLP, 2008.

YOUNG, P. Scientific social survey and research. New York: Prentice Hall, 1939.

Received: November 06, 2014

Accepted: December 20, 2014. 
PIOVANI, J. I. La formazione metodológica dei ricercatori sociali in America Latina. Sociologia e ricerca sociale, v. 104, 2014b, p. 147-156.

PIOVANI, J.I. et al. La enseñanza de la metodología en posgrados universitarios de Ciencias Sociales de Brasil. III Encuentro Latinoamericano de Metodología de las Ciencias Sociales. RedMetUManizales - UCaldas, Manizales, Colombia, 2012.

PIOVANI, J. I.; RAUSKY, E.; SANTOS, J. La enseñanza de la metodología en posgrados universitarios de Ciencias Sociales de Argentina. VII Jornadas de Sociología. UNLP, La Plata, Argentina, 2012.

TORTTI, C.; PIOVANI, J. I. Actas del I Encuentro Latinoamericano de Metodología de las Ciencias Sociales. La Plata: FaHCE-UNLP, 2008.

YOUNG, P. Scientific social survey and research. New York: Prentice Hall, 1939.

Received: March 06, 2015

Accepted: April 31, 2015. 